\title{
Unraveling the Role of Astrocytes in Subthalamic Nucleus Deep Brain Stimulation in a Parkinson's Disease Rat Model
}

\author{
Ana Carolina Pinheiro Campos ${ }^{1}$. Daniel Seicho Kikuchi ${ }^{2}$. Amanda Faure Nardini Paschoa ${ }^{1} \cdot$ Mayra Akemi Kuroki ${ }^{1}$. \\ Erich Talamoni Fonoff ${ }^{3}$. Clement Hamani ${ }^{4} \cdot$ Rosana Lima Pagano $^{1}$ (1) $\cdot$ Marina Sorrentino Hernandes ${ }^{2}$
}

Received: 15 October 2019 / Accepted: 31 December 2019 / Published online: 14 January 2020

(c) The Author(s) 2020

\begin{abstract}
Deep brain stimulation (DBS) of the subthalamic nucleus (STN) is an effective therapeutic strategy for motor symptoms of Parkinson's disease (PD) when L-DOPA therapy induces disabling side effects. Classical inflammatory activation of glial cells is well established in PD, contributing to the progressive neurodegenerative state; however, the role of DBS in regulating the inflammatory response remains largely unknown. To understand the involvement of astrocytes in the mechanisms of action of DBS, we evaluated the effect of STN-DBS in regulating motor symptoms, astrocyte reactivity, and cytokine expression in a 6-OHDA-induced PD rat model. To mimic in vivo DBS, we investigate the effect of high-frequency stimulation (HFS) in cultured astrocytes regulating cytokine induction and NF- $\kappa B$ activation. We found that STN-DBS improved motor impairment, induced astrocytic hyperplasia, and reversed increased IFN- $\gamma$ and IL-10 levels in the globus pallidus (GP) of lesioned rats. Moreover, HFS activated astrocytes and prevented TNF- $\alpha$-induced increase of monocyte chemoattractant protein-1 (MCP-1) and NF- $\mathrm{KB}$ activation in vitro. Our results indicate that DBS/HFS may act as a regulator of the inflammatory response in PD states, attenuating classical activation of astrocytes and cytokine induction, potentially through its ability to regulate NF- $\mathrm{BB}$ activation. These findings may help us understand the role of astrocyte signaling in HFS, highlighting its possible relationship with the effectiveness of DBS in neurodegenerative disorders.
\end{abstract}

Keywords Deep brain stimulation · High-frequency stimulation · Parkinson's disease $\cdot$ Inflammation · Astrocytes $\cdot \mathrm{NF}-\mathrm{kB}$

\section{Abbreviations}

6-OHDA 6-Hydroxydopamine

DBS Deep brain stimulation

FBS Fetal bovine serum

GFAP Glial fibrillary acidic protein

GP Globus pallidus

Rosana L. Pagano and Marina S. Hernandes jointly supervised this work.

Rosana Lima Pagano

rosana.lpagano@hsl.org.br

1 Division of Neuroscience, Hospital Sírio-Libanês, São Paulo, SP 01308-060, Brazil

2 Department of Medicine, Emory University, Atlanta, GA 30322, USA

3 Division of Neurosurgery, Department of Neurology, University of São Paulo Medical School, São Paulo 01246-903, Brazil

4 Sunnybrook Health Research Institute, Harquail Centre for Neuromodulation, Toronto, ON M4N 3M5, Canada
HFS High-frequency stimulation

IкB Nuclear factor of kappa light polypeptide gene enhancer in B-cell inhibitor

IFN Interferon

IL Interleukin

iNOS Inducible nitric oxide synthase

IR Immunoreactivity

MCP Monocyte chemoattractant protein

NF-кB Nuclear factor kappa-light-chain-enhancer of activated B cells

PB Phosphate buffer

PD Parkinson's disease

PFA Parafolmaldehyde

SN Substancia nigra

STN Subthalamic nucleus

TH Tyrosine hydroxylase

TNF Tumor necrosis factor 


\section{Introduction}

Deep brain stimulation (DBS) has been used worldwide in clinical practice with excellent results in several neurological diseases, including movement disorders, especially Parkinson's disease (PD) (Benabid 2003). Surgical candidates are those who either became refractory to conventional treatments or developed serious drug-induced side effects. DBS, as used to treat PD patients, involves applying high-frequency stimulation (HFS) through electrodes implanted in strategic nuclei, with the ability to adjust stimulation parameters to achieve optimal therapeutic benefits (Cicchetti and Barker 2014). Subthalamic nucleus (STN) DBS leads to improvements in motor symptoms, including rigidity, tremor, and bradykinesia, as well as L-DOPA-induced dyskinesias (Krack et al. 1997; Hamani et al. 2004; Goodman et al. 2006), improving patient's quality of life (Lagrange et al. 2002; Diamond and Jankovic 2005). Despite the widespread effectiveness of this technique, the specific mechanisms though which DBS improves clinical symptoms are still unclear. Data generated so far supports a role for DBS in modulating neurotransmission by altering the firing pattern of neurons (Beurrier et al. 2001; Dostrovsky and Lozano 2002; Hamani et al. 2011; Chiken and Nambu 2016). However, the output response of the STN after DBS is still unclear and contradictory (Benazzouz et al. 2000; Hamani et al. 2004, 2017; Harnack and Kupsch 2010; Hashimoto et al. 2013; Florence et al. 2016). While DBS does not seem to prevent dopaminergic degeneration in PD patients (Piboolnurak et al. 2007), in preclinical experiment stimulation, it has been shown to protect against dopaminergic loss in the nigrostriatal pathway (Maesawa et al. 2004; SpielesEngemann et al. 2010).

The importance of glial response in the neurodegenerative process of PD has been previously described (McGeer and McGeer 2008; Stott and Barker 2014). In response to a brain insult, reactive glial cells, such as astrocyte and microglia, release cytokines and reactive oxygen species (Dauer and Przedborski 2003; Sofroniew and Vinters 2010), which may contribute to neuronal cell damage and neurodegeneration (Anglade et al. 1997; Obeso et al. 2004). The transcriptional regulation of cytokines is mediated by the activation of the nuclear factor kappa-lightchain-enhancer of activated B cells (NF- $\mathrm{KB})$. The primary mechanism for canonical NF- $\kappa B$ activation includes the inducible degradation of the nuclear factor of kappa light polypeptide gene enhancer in B-cell inhibitor (IкB)- $\alpha$ (Duh et al. 1989; Verma et al. 1995; Gupta et al. 2010).

Reactive astrocytes can undergo a phenotypic switch from classical inflammatory (A1) to alternative antiinflammatory (A2), in analogy to the M1/M2 polarization for microglia/macrophage (Liddelow et al. 2017). It has been widely recognized that astrocytes adopt neurotoxic or neuroprotective phenotypes depending on the nature of the immune or inflammatory microenvironment (Jang et al. 2013; Jha et al. 2015). Thus, the inflammation-mediated neurodegenerative response depends not only on the presence of reactive astrocytes at the injury site, but also on their A1 or A2 functional polarization. Astrocytes are essential components of chemical synapses integrating the tripartite synapse (Araque et al. 1999; Perea et al. 2009). By releasing and uptaking neurotransmitters such as GABA, glycine, and glutamate, astrocytes are able to optimize and modulate neuronal communication (Sofroniew and Vinters 2010). However, in their A1 polarization state, the inflammatory phenotype inhibits the glutamate reuptake transporters altering the formation and quality of new synapses (Korn et al. 2005; Liddelow et al. 2017); hence, controlling inflammation is essential to regulate the synapses disruption. The role of DBS in reducing hippocampal neuroinflammation in epileptic rats has been previously described (Amorim et al. 2015), and the importance of astrocytes in response to stimulation has been discussed (Fenoy et al. 2014), but not yet tested. We postulated that DBS/HFS modulates classical inflammatory activation of astrocytes, contributing to the overall control of neuroinflammation in PD. To test this hypothesis, we characterized the effects of STN-DBS on the astrocytic phenotype of the globus pallidus (GP), an output nucleus of the STN, as well as on motor symptoms induced by 6-hydroxydopamine (6-OHDA) in a rat model of PD. In addition, to further understand the effects of DBS in astrocytes, we delivered HSF to cultured astrocytes prior to stimulation with tumor necrosis factor (TNF)- $\alpha$, which has been found to be increased in PD (Boka et al. 1994; Mogi et al. 2000; Nagatsu and Sawada 2005; Sawada et al. 2006). Our findings uncover a previously unknown role of HFS/DBS in astrocyte activation and advance our understanding of the mechanism involved in DBS in brain areas surrounding the stimulation target.

\section{Materials and Methods}

\section{Experimental Animals}

A total of 40 male Wistar rats (200-250 g) were used in this study. Rats were housed in acrylic boxes ( 3 rats per box) for at least a week before the experimental procedures were initiated. The animals were maintained in appropriate rooms with controlled light/dark cycle (12/12 h) and temperature $\left(22 \pm 2{ }^{\circ} \mathrm{C}\right)$ with wood shavings and free access to water and rat chow pellets. All animal experiments were conducted and reported in accordance with the ARRIVE 
guidelines (https://www.nc3rs.org.uk/arrive-guidelines). The protocols used during the execution of this project were approved by the Ethics Committee on the Use of Animals (CEUA) at Hospital Sírio-Libanês (SP, BRA), under protocol number CEUA 2016/04.

\section{Surgical Procedures for PD Model Induction and Electrode Implantation}

Animals were anesthetized with isoflurane (4\% induction, $2.5 \%$ maintenance in $100 \%$ oxygen) associated with local anesthesia ( $2 \%$ lidocaine, $100 \mu \mathrm{L} /$ animal on the scalp). Twelve $\mu \mathrm{g}$ of 6-hydroxydopamine (6-OHDA, SigmaAldrich, MO, USA) diluted in $2 \mu \mathrm{L}$ of $0.9 \%$ saline with $0.2 \%$ ascorbic acid was injected into two different points of the left striatum $(6 \mu \mathrm{g} / \mu \mathrm{L}$ of 6 -OHDA in each point) (Chudler and $\mathrm{Lu}$ 2008) under stereotaxic conditions. The injections were performed using a Hamilton syringe at the following coordinates: $+2.7 \mathrm{~mm}$ mediolateral, $0.0 \mathrm{~mm}$ anteroposterior, and $+4.5 \mathrm{~mm}$ dorsoventral (first point) $;+3.2 \mathrm{~mm}$ mediolateral, $+0.5 \mathrm{~mm}$ anteroposterior, and $+4.5 \mathrm{~mm}$ dorsoventral (second point), according to the rat brain atlas (Paxinos and Watson 2005). Control groups included animals injected with $1 \mu \mathrm{L}$ of saline in two different points of the left striatum. At the end of the injection, the needle was held in place for an additional 5 min to prevent backflow of the solution. In addition to 6-OHDA injections, a separate group of animals was implanted with insulated stainless steel electrodes $(250 \mu \mathrm{m}$ in diameter with $0.55 \mathrm{~mm}$ of surface exposed, Plastic One, CA, USA) into the left STN during the same surgical procedure. These electrodes were used as cathodes and implanted in the following coordinates: $+2.5 \mathrm{~mm}$ mediolateral, $-3.7 \mathrm{~mm}$ anteroposterior, and $+7.5 \mathrm{~mm}$ dorsoventral (Paxinos and Watson 2005). Screws implanted on the skull over the midbrain ( -6.0 anteroposterior and +2.5 lateral) were used as anodes (Paxinos and Watson 2005). Electrodes were fixed to the skull with dental acrylic cement. After the striatal injection and implantation of the electrode, animals were treated with meloxicam ${ }^{\circledR}$, a non-steroidal anti-inflammatory drug (NSAID) $(0.5 \mathrm{mg} /$ $\mathrm{kg}, \mathrm{SQ}$, Ourofino Pet, SP, BRA) and penicillin/streptomycin as prophylactic antibiotics $(0.2 \mathrm{mg} / \mathrm{kg}$, i.p., Zoetis, $\mathrm{SP}$, BRA). Rats were returned to their home cages and monitored until complete recovery from anesthesia. The regular diet was supplemented with a dietary supplement (Ensure, Abbott, SP, BRA) once a day for 3 consecutive days to ensure full recovery of the animals after the nigrostriatal injury. Following euthanasia, the location of the implants was confirmed through the Nissl-stained section.

\section{DBS Protocol}

Seven days after PD model induction and electrode implantation, a group of 6-OHDA animals were treated with 5 sessions of DBS (6-OHDA + DBS ON-biphasic cathodic pulses at $130 \mathrm{~Hz}, 60 \mu \mathrm{sec}$ pulse width, $0.1 \mathrm{~mA}, 2 \mathrm{~h}$ /day) using a portable stimulator (St Jude MTS, St Jude Medical, Plano, TX, USA). DBS was applied for 5 days from 9:00 AM to 11:00 AM. Control animals received 6-OHDA injections and had electrodes implanted, but no stimulation was delivered (6-OHDA + DBS OFF).

\section{Experimental Design-In Vivo}

Forty rats were randomly assigned to receive striatal 6-OHDA or saline injections under stereotaxic conditions, as described above. During the same surgical procedure, a separate group of animals had electrodes implanted into the left STN. Experimental groups were divided as follows: (1) Animals injected with striatal saline $(n=8),(2)$ Animals injected with striatal 6-OHDA $(n=8)$, (3) Animals injected with striatal 6-OHDA + DBS OFF (only electrode implanted) $(n=12)$, and (4) Animals injected with striatal 6-OHDA + DBS ON (stimulated) $(n=12)$. Seven days after the surgical procedure, animals were evaluated using immobility and rotation behavioral tests. From the 8th to the 12th day after the surgical procedure, 6-OHDA + DBS ON rats received DBS, as described above. After the last stimulation session (12 days after the surgical procedure), all experimental groups were re-evaluated in the immobility test. Immediately after the last behavioral test, half of the animals underwent transcardiac perfusion and their brains were collected to verify the correct positioning of the STN-DBS electrodes and for the evaluation of immunoreactivity (IR) for tyrosine hydroxylase (TH) in the substantia nigra (SN) and glial fibrillary acidic protein (GFAP) in the GP. Additionally, the other half of the animals were randomly selected and fresh brain tissue containing GP was quickly collected. Both electrode placement and cytokine levels (interleukin (IL)-1 $\beta$, IL-6, IL-10, and interferon (IFN)- $\gamma$ ) were evaluated (Fig. 1a).

\section{Apomorphine-Induced Rotational Behavior}

Apomorphine-induced rotational behavior was evaluated in order to validate the PD model, since the number of asymmetric rotations correlates with the degree of nigral degeneration, as previously demonstrated (Domenici et al. 2019). Rotational asymmetric behavior was evaluated using 


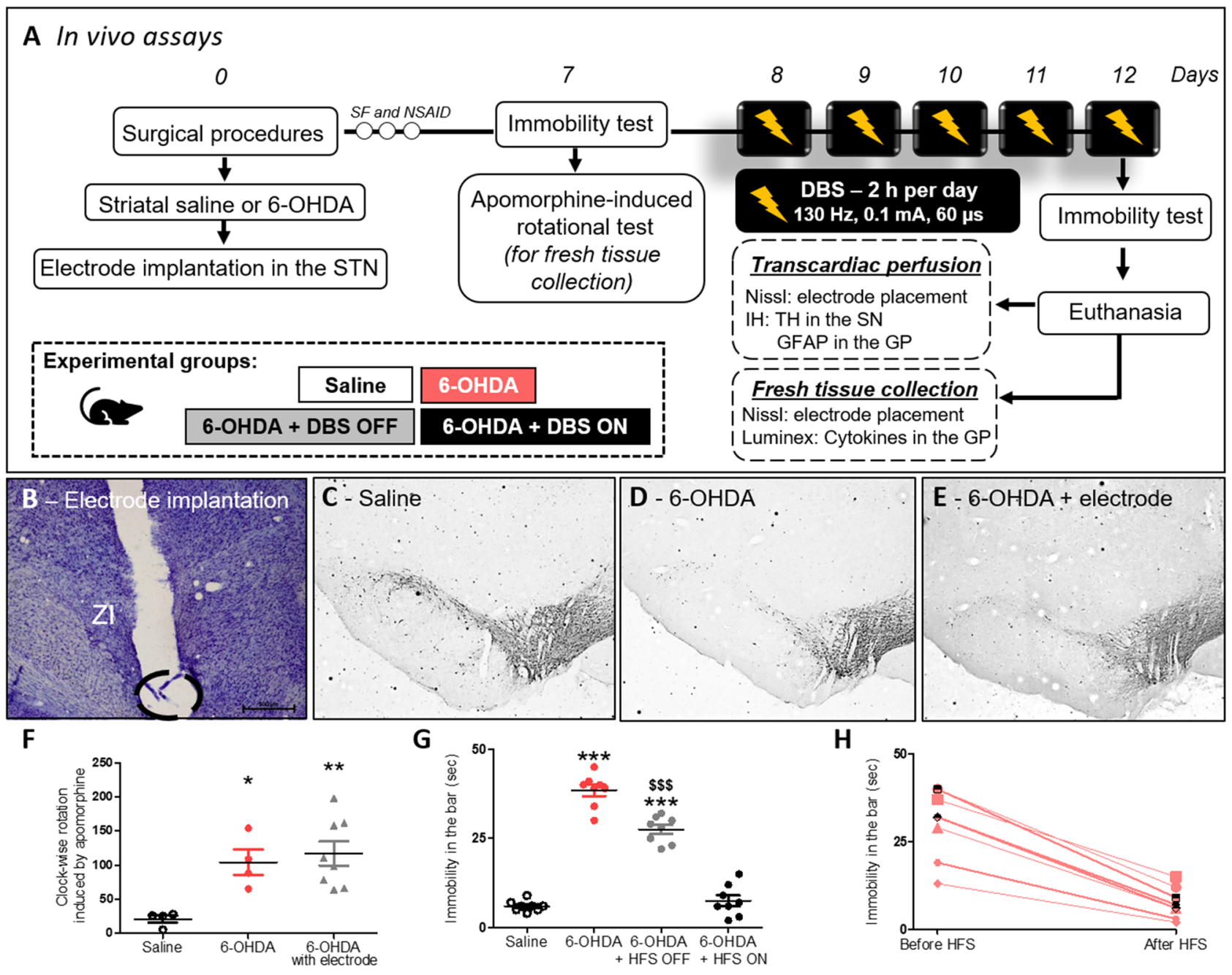

Fig. 1 Effect of STN-DBS on apomorphine-induced rotational behavior and immobility induced by 6-OHDA. a In vivo experimental design. b Nissl staining analysis to confirm electrode implantation in the STN. Representation of 6-OHDA-induced PD model in saline, 6-OHDA, and 6-OHDA + electrode OFF groups. c-e Immunohistochemistry for $\mathrm{TH}$ in the striatum showing 6-OHDA-induced dopaminergic degeneration in the SN. Images are representative of four independent experiments. f Apomorphine-induced rotational

an automatic rotometer system (Rota-Count 8, Columbus Instruments, OH, USA) 7 days after striatal saline or 6-OHDA injections. Animals receiving saline, 6-OHDA, 6-OHDA + DBS OFF, and 6-OHDA + DBS ON were injected with the dopaminergic agonist, apomorphine $(1 \mathrm{mg} /$ $\mathrm{Kg}$, s.c., Tocris Bioscience, BZ, UK), dissolved in 0.9\% saline, and evaluated over $30 \mathrm{~min}$, as previously described (Zhang et al. 2008). The criterion for rotation was a $180^{\circ}$ turn toward the side contralateral to the lesion. To reduce stress, rats were exposed to the automatic rotometer system for $30 \mathrm{~min}$ one day before the rotational test. None of the animals injected with 6-OHDA failed to present asymmetric rotational behavior and therefore no animals were excluded behavior was evaluated in order to confirm the dopaminergic deficit. Values represent the mean + SEM $(n=4-8)$. * $p<0.05 ; * * p<0.001$ vs. control saline group. $\mathbf{g}$ In vivo evaluation of immobility test following STN-DBS. Values represent the mean + SEM $(n=8$ per group). $* * * p<0.0001 \mathrm{vs}$. control saline group and $\$ \$ \$ p<0.0001 \mathrm{vs}$. 6-OHDA group. $\mathbf{h}$ Comparison between the immobility test performance before and after STN-DBS (immobility in the bar vs. before HFS in seconds) ( $n=8$ per group)

from the study. Rats injected with saline in striatum were also evaluated.

\section{Behavioral Immobility}

Seven days after PD model induction and following the fifth DBS session (day 12), animals were evaluated in the bar test to measure akinesia (typical catalepsy test). Saline control animals and 6-OHDA-injected animals that were not subjected to DBS were also evaluated after 12 days of striatal injections. The immobility test consists of placing an animal in an unusual posture and recording the 
time that the animal takes to correct his posture (Sanberg 1980). Behavioral immobility was characterized by muscle rigidity and failure to correct an imposed posture for a prolonged period. In this test, the animals were positioned with both forepaws on a 9-cm horizontal bar $(0.9$ $\mathrm{cm}$ diameter). The time course during which the animal remained motionless in this imposed posture was considered the bar test elapsed time (with a cutoff time of $120 \mathrm{~s}$ ). The behavioral immobility endpoint was considered when both forepaws were removed from the bar or when the animal moved its head in an exploratory manner.

\section{Immunohistochemistry}

After the last behavioral test (12 days), animals were anesthetized with ketamine/xylazine $(0.5 / 2.3 \mathrm{mg} / \mathrm{Kg}$, respectively, i.p.) and then submitted to transcardial perfusion with $0.9 \%$ saline solution, followed by $4 \%$ paraformaldehyde (PFA) dissolved in $0.1 \mathrm{M}$ phosphate buffer (PB, $\mathrm{pH}$ 7.4). Their brains were collected and postfixed in PFA for $4 \mathrm{~h}$, followed by incubation with $30 \%$ sucrose solution in PB for $48 \mathrm{~h}$ at $4{ }^{\circ} \mathrm{C}$. Tissue sections $(40 \mu \mathrm{m})$, obtained using a freezing sliding microtome, were kept under constant agitation and subjected to the following steps: (a) Incubation for $12-16 \mathrm{~h}$ at $4{ }^{\circ} \mathrm{C}$ with specific primary antibodies to mouse anti-TH (1:1000, MAB5280, Millipore, MA, USA) or mouse anti-GFAP (1:1000, G3893, SigmaAldrich) diluted in $0.3 \%$ triton X-100, containing 5\% normal donkey serum (Jackson ImmunoResearch, ME, USA); (b) Incubation for $2 \mathrm{~h}$ at room temperature with biotinylated secondary antibodies (1:200, Jackson ImmunoResearch), and (c) Incubation with avidin-biotin-peroxidase complex (1:100, ABC Elite kit, Vector Labs, CA, USA). Labeling was developed with $0.05 \%$ diaminobenzidine tetrahydrochloride (DAB, Sigma-Aldrich) and $0.03 \%$ hydrogen peroxide in $\mathrm{PB}$. Tissue sections were washed between each step $(3 \times 10 \mathrm{~min})$. The sections were mounted on glass slides, air-dried, dehydrated, and coverslipped. Finally, images were obtained utilizing a light microscope (Eclipse E1000, Nikon, NY, USA). The regions of interest, including the SN (from bregma -6.60 to $-6.00 \mathrm{~mm}$ anteroposterior, -1.00 to $-3.2 \mathrm{~mm}$ mediolateral, and -7.2 to $-8.8 \mathrm{~mm}$ dorsoventral) and GP (from bregma -1.44 to $3.72 \mathrm{~mm}$ anteroposterior, -2.4 to $-3.8 \mathrm{~mm}$ mediolateral , and -5.00 to $-7.8 \mathrm{~mm}$ dorsoventral), were identified based on a stereotaxic atlas (Paxinos and Watson 2005). Using ImageJ software (National Institutes of Health, MD, USA; https://rsbweb.nih.gov/ij/), the TH-IR and the number of GFAP-positive cells were analyzed per area $\left(\mathrm{mm}^{2}\right)$. Measurements were taken from five sections per animal and five animals per group.

\section{Luminex}

After the last behavioral test (12 days), half of the animals were euthanized by decapitation, the GP was freshly dissected and gently homogenized at $4{ }^{\circ} \mathrm{C}$ in radioimmunoprecipitation assay (RIPA) buffer (50 $\mathrm{mM}$ Tris, $150 \mathrm{mM}$ $\mathrm{NaCl}, 1 \mathrm{mM}$ EDTA, $0.1 \%$ SDS, $0.5 \%$ deoxycholate, $1 \%$ NP-40) with fresh protease inhibitors. The Luminex assay was used to quantify levels of IL-1 $\beta$, IL-6, IL-10, and IFN- $\gamma$ (RECYTMAG-65 K, Millipore). The assay was carried out in accordance with the manufacturer's recommendations.

\section{Nissl Staining}

The confirmation of electrode placement in the STN was evaluated by a retrospective analysis of Nissl-stained coronal sections. In half of the animals in each group, the fixed brain sections obtained using a freezing sliding microtome, as described above, were mounted onto gelatin-subbed slides. In the other half of the animals, slices approximately $2 \mathrm{~cm}$ thick containing the GP were freshly collected and frozen in OCT compound (SigmaAldrich). Tissue sections $(20 \mu \mathrm{m})$ were obtained using a cryostat and mounted onto gelatin-subbed slides. Brain sections were then incubated in cresyl violet solution $(1 \mathrm{~g}$ of cresyl violet $+10 \mathrm{~mL}$ of $100 \%$ acetic acid and $1 \mathrm{~L}$ of distilled water) for $30 \mathrm{~min}$ at room temperature, washed in distilled water, dehydrated in an ascending ethanol series (70\%, 95\%, and 100\%), and incubated in xylene solution. Sections were mounted in Permount Mounting Medium and the images were acquired using a light microscope (Eclipse E1000, Nikon).

\section{Cell Culture and HFS Stimulation}

C8-D1A mouse type I astrocytes (CRL-2541, ATTC, MD, USA) were cultured in DMEM/F12 media (Invitrogen, MA, USA) supplemented with $10 \%$ fetal bovine serum (FBS), $2 \mathrm{mM} / \mathrm{L}$ L-glutamine, 100 units $/ \mathrm{mL}$ penicillin, and $100 \mathrm{mg} / \mathrm{mL}$ streptomycin. Cells were plated on collagencoated culture dishes and the medium was changed every 2 days until cells reached $80 \%$ confluence. Cells were used between passages 4 to 10 and seeded at a density of $2 \times 10^{5}$ cells per $60 \mathrm{~mm}^{2}$ dish for experiments. 


\section{Experimental Design—In Vitro}

TNF- $\alpha$ was used to stimulate astrocytes mimicking higher concentrations found in response to induced PD model (Boka et al. 1994; Mogi et al. 2000; Nagatsu and Sawada 2005). Cells were incubated in $0.1 \%$ FBS in DMEM/F12 media overnight and stimulated with TNF- $\alpha(100 \mathrm{ng} / \mathrm{mL}$, PeproTech, NJ, USA) for 1, 3, 6 or $24 \mathrm{~h}$ (Fig. 3a). IL-6 and monocyte chemoattractant protein (MCP)-1 mRNA levels were analyzed. In each experiment, cultures exposed to TNF- $\alpha$ were compared with PBS control conditions. In

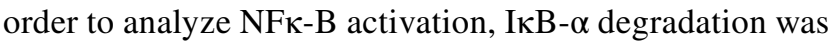
investigated at different time points following TNF- $\alpha$ stimulation for 15, 30, or $60 \mathrm{~min}$ (Fig. 3b). For the investigation of HFS, cells were cultured in plastic dishes and two monopolar tungsten electrodes were submerged in media with care taken to ensure no direct contact with the cell layer. The electrodes were connected to the same portable stimulator (St Jude MTS) used for in vivo experiments. Cultured astrocytes were stimulated with biphasic cathodic pulses at $130 \mathrm{~Hz}(0.1 \mathrm{~mA}$ and $60 \mu \mathrm{sec}$ pulse width) for $6 \mathrm{~h}$ through. Cells were subjected to HFS for $6 \mathrm{~h}$ and during the last hour of stimulation TNF- $\alpha$ was added to the culture media. IL-6 and MCP-1 levels were analyzed at the mRNA and protein levels (Fig. 4a). Additionally, cells were subjected to HFS for $6 \mathrm{~h}$ and during the last $15 \mathrm{~min}$ of stimulation TNF- $\alpha$ was added to the culture media and

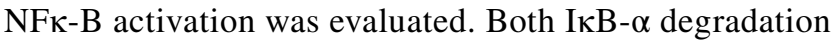
(in whole cell lysate) and p65 nuclear translocation (in subcellular fractionation) were analyzed. Additional control conditions included cells with or without TNF- $\alpha$ and not electrically stimulated (Fig. 5a).

\section{Real-Time Polymerase Chain Reaction (RT-PCR)}

Total RNA was extracted with the RNeasy Plus kit (Qiagen, MA, USA). Reverse transcription was performed using Superscript II reverse transcriptase (Invitrogen) with random primers and cDNA was purified with the QIAquick kit (Qiagen). cDNA was amplified with primers against IL-6 (F:GTCTATACCACTTCACAAGTC,R:TGC ATCATCGTTGTTCATAC), MCP-1 (F:AGCACCAGC CAACTCTCACT, R:TCTGGACCCATTCCTTCTTG), and RPL (housekeeping gene-F:ATGACAAGAAAA AGCGGATG, R:CTTTTCTGCCTGTTTCCGTA) using Platinum Taq DNA polymerase (Invitrogen,) in the presence of SYBR green I. Reactions were carried out in glass capillaries, using the LightCycler 1.2 (Roche, MA, USA) real time thermocycler. Data analysis was performed using the mak3 module of the qpcR software library in the $\mathrm{R}$ environment.

\section{Western Blotting}

\section{Whole Cell Lysate}

Whole cell lysate was prepared using triton buffer $(25 \mathrm{mM}$ HEPES, $100 \mathrm{mM} \mathrm{NaCl}, 1 \mathrm{mM}$ EDTA, and 1\% Triton $\mathrm{x}-100$ ) with $10 \mu \mathrm{g} / \mathrm{mL}$ aprotinin, $10 \mu \mathrm{g} / \mathrm{mL}$ leupeptin, $1 \mathrm{mM}$ PMSF, and Halt phosphatase inhibitor cocktail $(78,428$, Thermo Fisher Scientific, CA, USA). Samples were processed using a tissue homogenizer before sonification and centrifugation. The Bradford assay (Bio-Rad, CA, USA) was used to measure protein concentrations. The samples were diluted in Laemmli buffer for separation using SDS-PAGE. Following electrophoretic separation, proteins were transferred to a PVDF membrane ( $0.2 \mu \mathrm{m}$ in diameter, Millipore), blocked for $1 \mathrm{~h}$ at room temperature with 5\% BSA in Tris-Saline buffer, and the membranes were incubated overnight at $4{ }^{\circ} \mathrm{C}$ with the rabbit anti-IкB- $\alpha$ (1:2000, \#ab32518, Abcam, UK) or rabbit anti- $\beta$-tubulin (1:5000, \#ab6046, Abcam) diluted in $0.1 \%$ Tween-20 (TBST). The membranes were then washed with TBST and incubated for $2 \mathrm{~h}$ with the appropriate peroxidase-labeled secondary antibodies (1:2000, Amersham Biosciences, NJ, USA) diluted in TBST. The excess conjugate was removed with an added further wash cycle and the antigens were developed using the chemiluminescence ECL Kit (Amersham Biosciences) and analyzed for the density of the labeled bands using the ImageJ software. The anti- $\beta$ tubulin was used as loading control and the control group was normalized to 100 for comparison with other groups.

\section{Subcellular Fractionation}

Whole cell lysate was prepared from cultured astrocytes using NP-40 buffer (0.1\% NP40 with PBS). Homogenates were centrifuged at $10,000 \mathrm{rpm}$. The supernatant (cytosolic fraction) was collected and the nuclear pellet was resuspended in NP-40 buffer and further pelleted. The final nuclear pellet was then resuspended in $0.1 \%$ Triton and Laemmli buffer (Bio-Rad) for separation by SDS-PAGE, as described above. The membranes were incubated overnight at $4{ }^{\circ} \mathrm{C}$ with the rabbit anti-p65 (1:1000, \#8242, Cell Signaling, MA, USA), rabbit anti-Histone 3 (1:500, \#07-354, Millipore), or rabbit anti- $\beta$-tubulin (1:5000, Millipore) diluted in TBST. The membranes were then washed with TBST and incubated for $2 \mathrm{~h}$ with the appropriate peroxidase-labeled secondary antibodies (1:2000, Amersham Biosciences) diluted in TBST. The excess conjugate was removed with a further wash cycle and the antigens were developed using 
the chemiluminescence ECL Kit (Amersham Biosciences) and analyzed for the density of the labeled bands using the ImageJ software. Histone 3 and $\beta$-tubulin were used as loading controls for nuclear and cytosolic fractions.

\section{ELISA}

Whole cell lysate was prepared from cultured astrocytes using a radioimmunoprecipitation assay (RIPA) buffer (50 mM Tris, $150 \mathrm{mM} \mathrm{NaCl}, 1 \mathrm{mM}$ EDTA, 0.1\% SDS, 0.5\% deoxycholate, and 1\% NP-40) with fresh protease inhibitors. MCP-1 expression analysis in cell lysate and cell supernatant was performed according to the manufacturer's instructions (R\&D, Minneapolis, MN, USA).

\section{Statistical Analysis}

For animal studies, results obtained were expressed as means \pm standard error of the mean (SEM). For cell culture results, data are expressed as means \pm standard deviation of the mean (SD). Data were analyzed using GraphPad Prism (CA, USA) and statistical significance was assessed using ANOVA, followed by Tukey's multiple comparison post hoc tests. Analysis of akinesia before and after DBS was calculated using the paired $t$-test. In all cases, $p<0.05$ was considered statistically significant.

\section{Results}

\section{STN-DBS Improves Motor Impairment}

Rats subjected to a unilateral 6-OHDA-induced PD model presented loss of TH-IR in the SN pars compacta (Fig. 1d and e) and asymmetric rotation to the contralateral side of the lesion (1-w-ANOVA; $F_{(2,15)}=7.524, p=0.0067$, followed by Tukey's post hoc test; Fig. 1f) when compared with salineinjected control rats (Fig. 1c and f). Electrode localization in the STN was confirmed with Nissl staining, as represented in Fig. 1b. Eight animals had electrodes incorrectly positioned and were excluded from the study (data not shown). The electrode implantation per se (6-OHDA + DBS OFF group) did not prevent either 6-OHDA-induced loss of TH-IR (Fig. 1e) or asymmetric rotational behavior (Fig. 1f). As for the immobility test, striatal 6-OHDA increased the latency spent in the bar when compared to the saline group (Fig. 1g). The presence of the electrode itself (6-OHDA + DBS OFF group) significantly decreased the time spent in the bar when compared with the 6-OHDA group (1-w-ANOVA; $F_{(3,31)}=142.3, p<0.0001$, followed by Tukey's post hoc test; Fig. 1g). STN-DBS reduced neurotoxin-induced behavioral immobility when compared to the 6-OHDA group (Fig. 1g) and baseline responses before DBS (Fig. 1h).

\section{STN-DBS Does not Alter the Hyperplasia of Astrocytes, but Changes the Inflammatory Pattern in the Globus Pallidus}

Thirteen days following its administration, 6-OHDA induced hyperplasia of astrocytes in the GP (1-w-ANOVA; $F_{(3,15)}=43.86, p<0.0001$, followed by Tukey's post hoc test; Fig. $2 \mathrm{~b}$ and e), when compared to saline-injected controls (Fig. 2a and e). In addition, while no difference in IL- $1 \beta$ expression was observed in the GP (1-w-ANOVA; $F_{(3,15)}=5.518, p>0.05$, followed by Tukey's post hoc test; Fig. 2f), 6-OHDA induced a significant decrease in IL-6 protein levels (1-w-ANOVA; $F_{(3,15)}=18.54, p<0.0001$, followed by Tukey's post hoc test; Fig. $2 \mathrm{~g}$ ) and an increase in IL-10 (1-w-ANOVA; $F_{(3,15)}=19.97, p<0.0001$, Fig. $\left.2 \mathrm{~h}\right)$ and IFN- $\gamma$ expression ( 1 -w-ANOVA; $F_{(3,15)}=27.60, p<0.0001$, followed by Tukey's post hoc test; Fig. 2i) when compared to saline-injected control animals. DBS OFF was not able to attenuate 6-OHDA-induced astrocytic hyperplasia (Fig. 2a-d) in the GP, when compared to saline-injected control animals. In addition, DBS (6-OHDA + DBS ON group) significantly inhibited the effect of 6-OHDA on the hyperplasia phenomenon of astrocytes (Fig. 2e). Regarding cytokine levels, DBS-stimulated 6-OHDA animals presented decreased IL- $1 \beta$ expression, when compared to saline control animals (Fig. 2f), and completely attenuated IL-10 and IFN- $\gamma$ expression (Fig. $2 \mathrm{~h}$ and i, respectively), when compared to 6-OHDA-injected animals.

\section{TNF-a Induces Classical Inflammatory Activation of Astrocytes In Vitro}

To determine whether cultured resting astrocytes (A0 subtype) would exhibit characteristics of classical inflammatory astrocytes (A1-like subtype) (Fig. 3c), cells were treated with TNF- $\alpha$ at different time points $(1,3,6$, and $24 \mathrm{~h})$ and the expression of IL- 6 and MCP-1 mRNA was analyzed. As expected, IL-6 mRNA levels ( 1 -w-ANOVA; $F_{(4,19)}=4.925$, $p=0.0097$; followed by Tukey's post hoc test; Fig. 3d) and MCP-1 levels ( 1 -w-ANOVA; $F_{(4,19)}=10.46, p=0.0072$; followed by Tukey's post hoc test; Fig. 3e) were found to be significantly upregulated following TNF- $\alpha$ treatment when compared with non-stimulated control cells. To investigate the time course of NF- $\mathrm{KB}$ activation in astrocytes in vitro, I $\kappa \mathrm{B}-\alpha$ degradation was monitored following TNF- $\alpha$ treatment for 15,30 , and $60 \mathrm{~min}$. IкB- $\alpha$ protein levels were found to be significantly decreased 15 min after the TNF- $\alpha$ treatment and returned to baseline levels $60 \mathrm{~min}$ after 

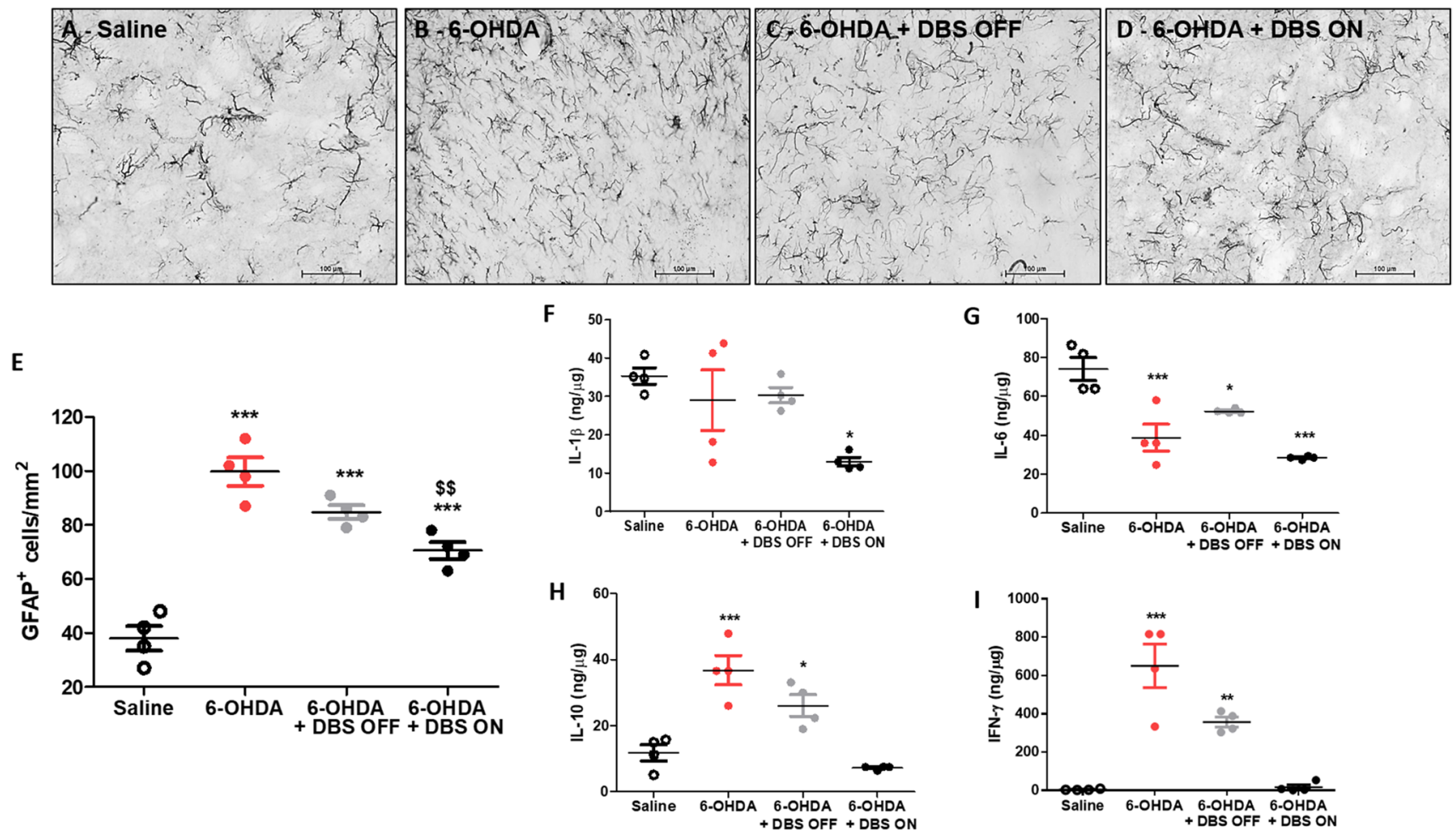

Fig. 2 Pallidal inflammation following STN-DBS in vivo. a-d Photomicrographs of immunoreactivity for GFAP in saline (a), 6-OHDA (b), 6-OHDA + DBS OFF, (c) and 6-OHDA + DBS ON (d) and e quantification of GFAP + cells in the GP $(n=4)$. $\mathbf{f}-\mathbf{i}$ In vivo evalua-

stimulation, when compared with control non-stimulated cells $\left(1\right.$-w-ANOVA; $F_{(4,19)}=3.68, p=0.0171$, followed by Tukey's post hoc test; Fig. 3f).

\section{HFS Prevents MCP-1, but not IL-6 Induction in Cultured Astrocytes Following TNF-a Treatment}

To investigate whether HFS inhibits TNF- $\alpha$-induced cytokine expression, astrocytes were exposed to $6 \mathrm{~h}$ of HFS and TNF- $\alpha$ was added to the culture media during the last hour of HFS stimulation (see experimental design in Fig. 4a). Similar to our in vivo findings (Fig. 2g), HFS ON did not prevent TNF- $\alpha$-stimulated IL-6 mRNA levels induction, as shown in Fig. $4 \mathrm{~b}$ (1-w-ANOVA; $F_{(3,19)}=3.994$, $p=0.1071$; followed by Tukey's post hoc test). On the other hand, HFS ON prevented TNF- $\alpha$-induced increases in MCP-1 mRNA levels $\left(F_{(3,19)}=14.96, p=0.0002\right.$; followed by Tukey's post hoc test; Fig. 4c). Corroborating our mRNA expression data, HFS ON prevented TNF- $\alpha$-induced MCP-1 protein levels in cell lysates (1-w-ANOVA; $F_{(3,19)}=12.93$, $p=0.0002$; followed by Tukey's post hoc test; Fig. $4 \mathrm{~d}$ ) and in the culture supernatant $\left(F_{(3,19)}=35.09, p<0.0001\right.$; tion of expression levels of IL-1 $\beta$ (f), IL-6 (g), IL-10, (h) and IFN- $\gamma$ (i) in the GP. Values represent the mean + SEM of four independent experiments. ${ }^{*} p<0.05 ; * * p<0.001, * * * p<0.0001$ vs. saline-injected control animals. $\$ \$ p<0.001$ vs. 6-OHDA group

Fig. 4e). The presence of the electrode itself (TNF- $\alpha+$ HFS OFF group) did not prevent TNF- $\alpha$-stimulated cytokine induction (TNF- $\alpha$ vs. TNF- $\alpha+$ HFS OFF group) (Fig. $4 b-e$ ).

\section{HFS Inhibits NF-kB Signaling Pathway in Astrocytes}

Because NF- $\mathrm{KB}$ is known to regulate transcription of MCP-1 (Rovin et al. 1995), we hypothesized that HFS affects the NF- $\kappa B$ signaling pathway. To investigate whether HFS interferes with the TNF- $\alpha$-induced NF- $\kappa B$ activation in cultured astrocytes, the protein expression of the NF- $\kappa B$ inhibitor $\mathrm{I} \kappa \mathrm{B}-\alpha$ was evaluated. Because I $\mathrm{KB}-\alpha$ protein expression was found to be significantly decreased 15 min after TNF- $\alpha$ stimulation (Fig. 3f), we exposed astrocytes to HFS for $6 \mathrm{~h}$, added TNF- $\alpha$ to their culture media during the last $15 \mathrm{~min}$ of stimulation (see experimental design in Fig. 5a), and evaluated IкB- $\alpha$ degradation. HFS significantly prevented I $\kappa$ B- $\alpha$ protein degradation (1-w-ANOVA; $F_{(3,19)}=9.050$, $p=0.0012$; followed by Tukey's post hoc test; Fig. $5 \mathrm{~b}$ ). In addition, HFS also prevented TNF- $\alpha$-induced p65 translocation to the nuclear fraction in cultured astrocytes 

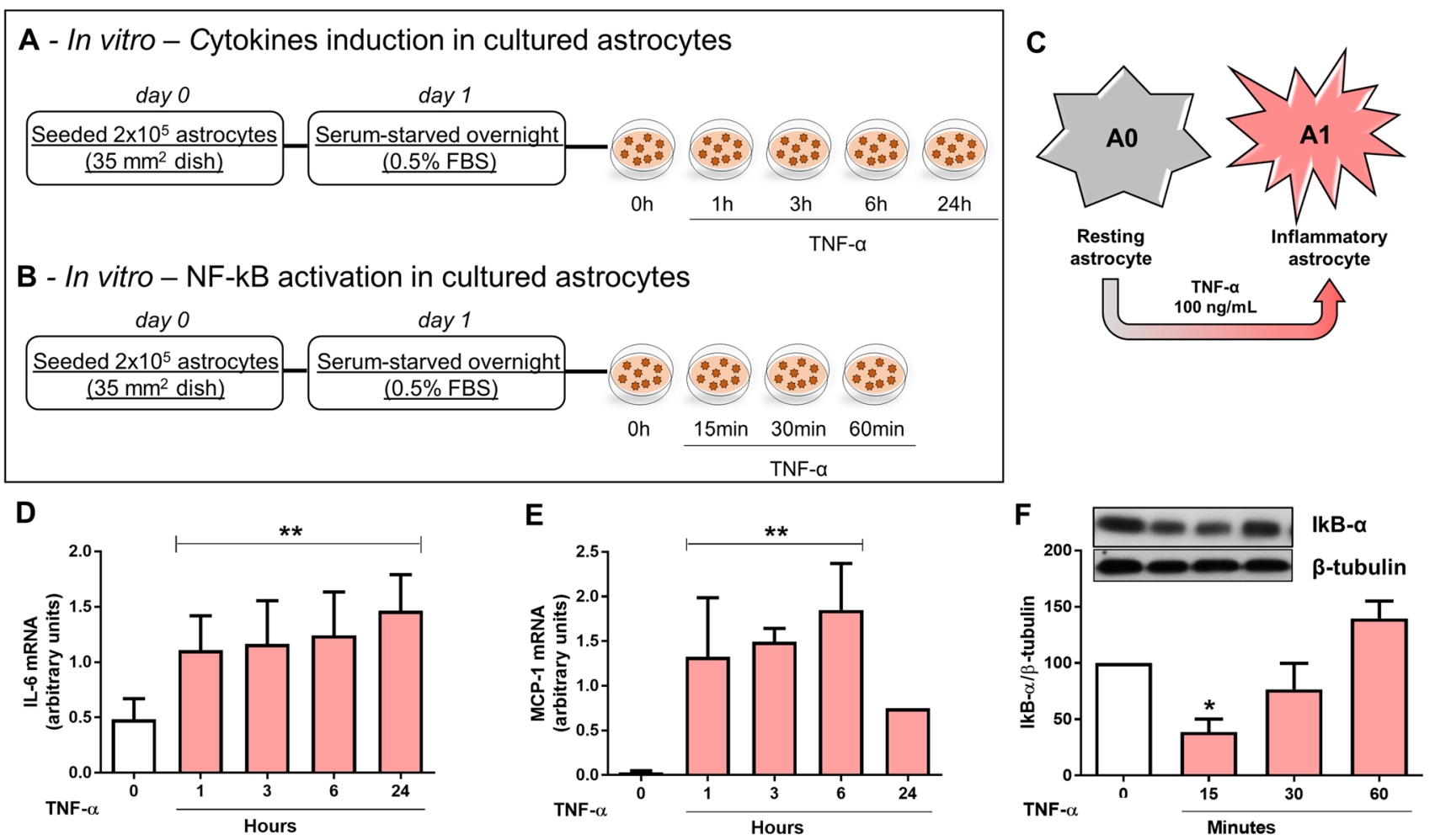

Fig. 3 Effect of TNF- $\alpha$ on astrocyte activation in vitro. $\mathbf{a}, \mathbf{b}$ In vitro experimental design and $\mathbf{c}$, scheme representing astrocyte phenotypic switch from resting A0 to classical inflammatory A1. d, e Astrocytes were stimulated with TNF- $\alpha$ for $1,3,6$, or $24 \mathrm{~h}$ and IL-6 (d) and MCP-1 (e) mRNA levels were analyzed by RT-PCR. Bar graphs represent means $\pm \mathrm{SD}$ of five independent experiments normalized to
RPL. ${ }^{*} p<0.001$ when compared to control non-stimulated cells. $\mathbf{f}$ Astrocytes were stimulated with TNF- $\alpha(0,15,30$ and $60 \mathrm{~min})$ and I $\kappa \mathrm{B}-\alpha$ protein expression was evaluated by western blotting and normalized to $\beta$-tubulin. Bar graphs represent means \pm SD of five independent experiments. $* p<0.05$ vs. control non-stimulated cells

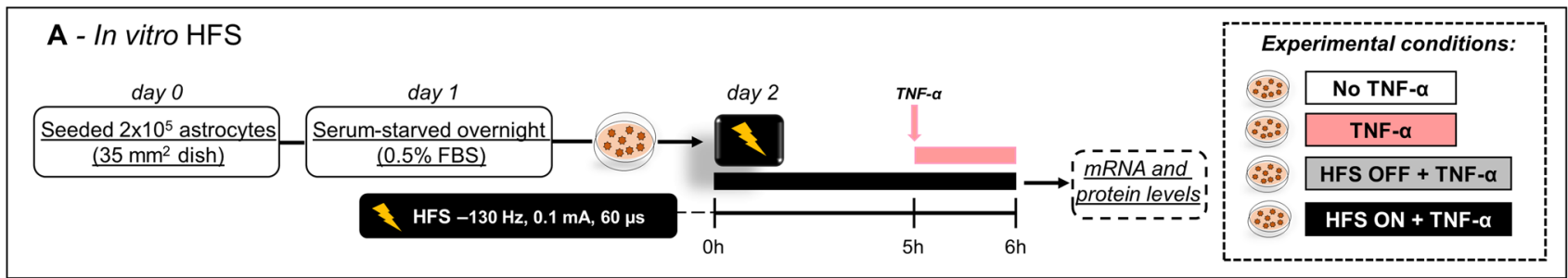

B

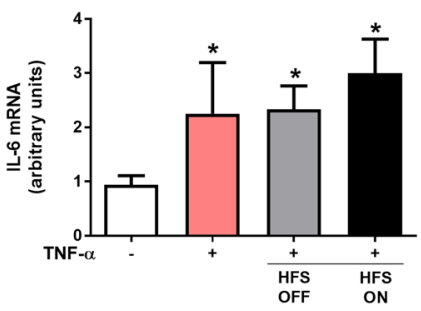

C

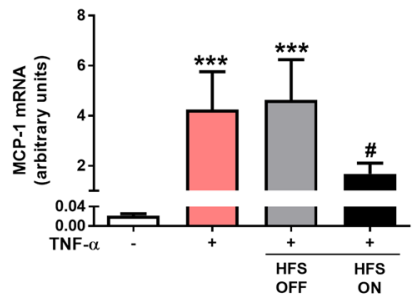

D

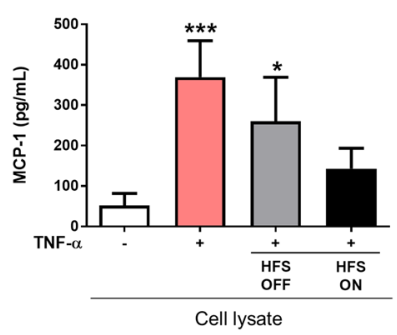

E

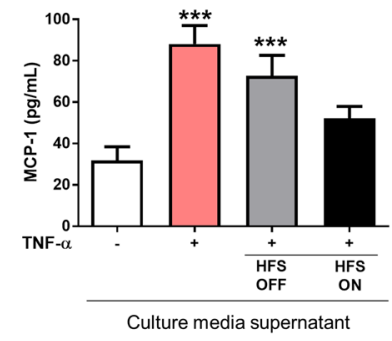

Fig. 4 Effect of HFS on TNF- $\alpha$-stimulated cytokine induction. a In vitro experimental design. Astrocytes were stimulated with HFS (HFS ON) for $6 \mathrm{~h}$, TNF- $\alpha$ was added to the culture media during the last hour of stimulation, and cytokine mRNAs and proteins were measured. b, c IL-6 (b) and MCP-1 mRNA expression (c) were analyzed by RT-PCR and normalized to RPL. Bar graphs represent means \pm SD of five independent experiments. $* p<0.05$, $* * * p<0.001$ vs. control non-stimulated cells and $\# p<0.05$ vs. TNF- $\alpha$-treated cells. d, e MCP-1 protein expression was measured by ELISA in cell lysates (d) and in cell culture supernatant (e). Bar graphs represent means $\pm \mathrm{SD}$ of five independent experiments. $* p<0.05$ and $* * * p<0.001$ vs. control non-stimulated cells 


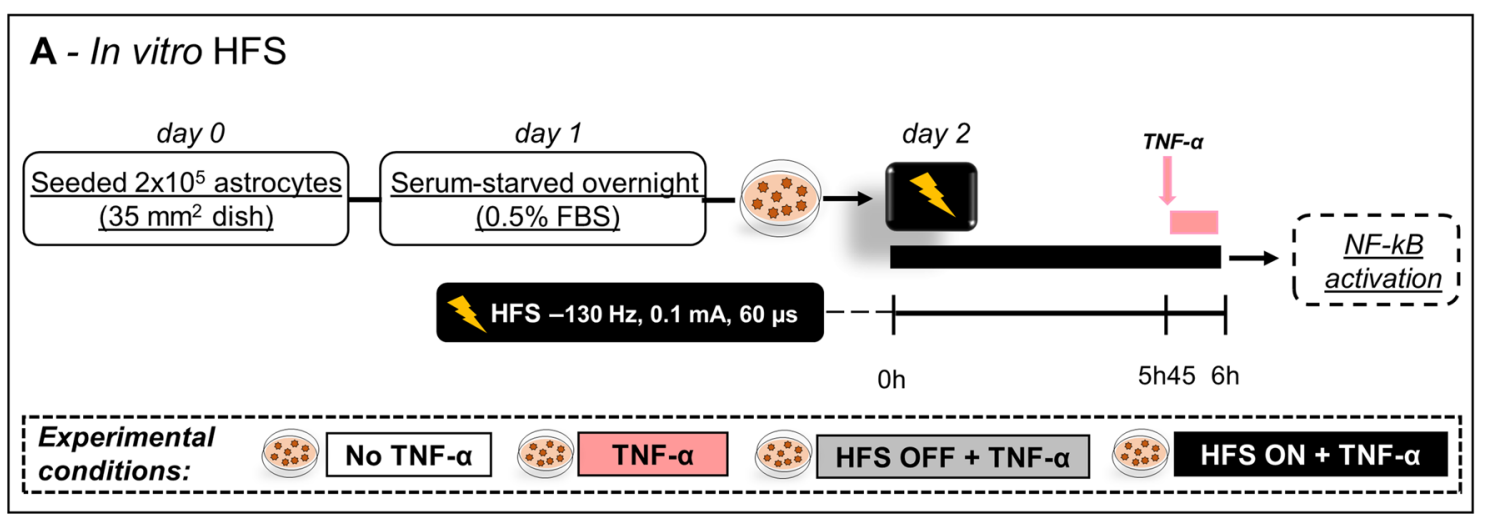

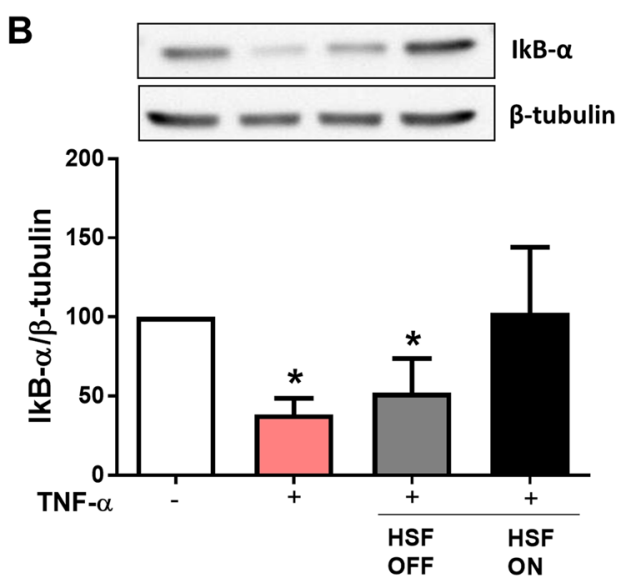

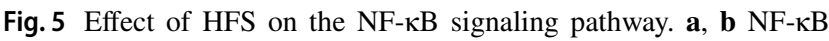
signaling pathway was assessed by Western blot in astrocytes submitted to HFS (HFS ON, $6 \mathrm{~h}$ ) and TNF- $\alpha$ (15 min) (a), and the IкB- $\alpha$ protein expression was evaluated in whole cell lysates using Western blotting and corrected for $\beta$-tubulin (b). c Astrocytes were stimulated

$\left(1\right.$-w-ANOVA; $F_{(3,19)}=12.45, p=0.0015$; followed by Tukey's post hoc test; Fig. 5c).

\section{Discussion}

STN-DBS has been widely used for the treatment of advanced PD when long-term treatment with dopaminergic agents induces debilitating side effects (Kumar et al. 1998; Benabid et al. 2009; Cury et al. 2016; dos-SantosPereira et al. 2016). DBS at intermediate stages of PD has been shown to provide superior benefits when compared to advanced $\mathrm{PD}$, preventing severe complications resulting from medication at high doses, tolerability, and optimization of the technique's effectiveness. Early DBS has been shown to improve quality of life and delay the appearance of motor fluctuations, dyskinesias, and functional disability (Charles et al. 2012; Hacker et al. 2015, 2016). Considering all the aforementioned observations, we have chosen to use a DBS protocol at the early-onset of 6-OHDA-induced
C
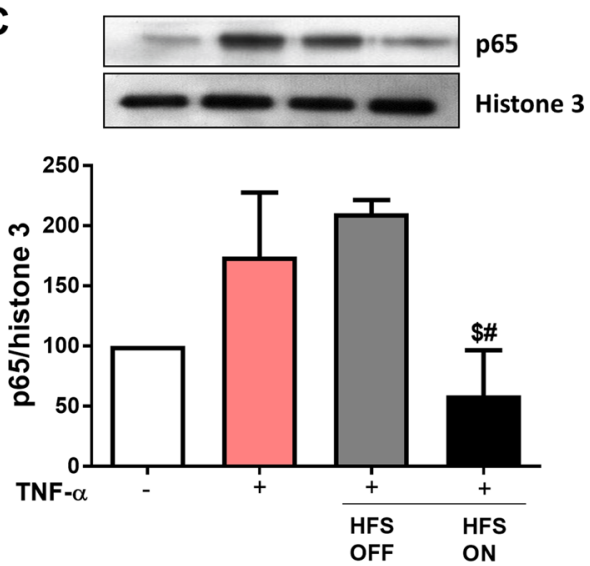

with HFS and the p65 protein expression was evaluated in the nuclear fraction using Western blotting and corrected according to histone 3 . Bar graphs represent means $\pm \mathrm{SD}$ of five independent experiments. $* p<0.05$ when compared to control no TNF- $\alpha$; \#p<0.05 when compared to TNF- $\alpha+;{ }^{\$} p<0.05$ when compared to TNF- $\alpha+$ HFS OFF

$\mathrm{PD}$, in which approximately $50 \%$ of dopaminergic neuronal loss is observed in the SN 7 days after a 6-OHDA injection, mimicking the neuronal loss observed in patients at earlier stages of PD (Marsden 1990; Lang and Lozano 1998; Dauer and Przedborski 2003; Ross et al. 2004).

We show that STN-DBS was able to improve motor impairment (akinesia) induced by 6-OHDA. In addition, our data is consistent with clinical studies in which STN-DBS significantly enhanced daily activities and improved motor symptoms in the "off" medication condition (Kleiner-Fisman et al. 2006). Remarkably, it has been observed that the electrode insertion effect in the STN per se seems to effectively improve PD symptoms (Benazzouz et al. 1993; Benabid et al. 1994), probably by mimicking the effects of STN inactivation (Florence et al. 2016; Hamani et al. 2017). In our study, we observed a $25 \%$ reduction in the time animals spent in the bar in the 6-OHDA + DBS OFF group when compared to 6-OHDA animals with no electrode implanted. Because of the small dimensions of the STN, this response could have occurred due to a STN microlesion effect 
(Fig. 1b). A limitation of our in vivo experimental approach is that the ratio of electrode size to target in rodents is very different from that observed in humans. We note, however, that microlesion effects are also commonly observed in clinical practice.

Several PD models in rats have been shown to induce glial cell activation in the SN and striatum (McGeer and McGeer 2008; Sanchez-Guajardo et al. 2015; Booth et al. 2017; Joers et al. 2017). GFAP staining has been widely used as a marker of reactive astrocytes. Its increased expression is characteristic of astrocytic hyperplasia/hypertrophy (Sofroniew and Vinters 2010) which is a hallmark of neuropathological conditions such as Alzheimer's and PD (McGeer and McGeer 2008). Reactive gliosis around implanted DBS electrodes has been reported (Stock et al. 1979; Haberler et al. 2000; Sun et al. 2008). In astrocytes, electrical stimulation induces hyperpolarization and low input resistance compared to neurons (Amzica and Neckelmann 1999; Amzica et al. 2002; Mishima et al. 2007). As a consequence, HFS/DBS induces an increase in adenosine and glutamate levels in astrocytes and seems to induce astrocytic $\mathrm{Ca}^{2+}$ waves that propagate away from the stimulation site (Bekar et al. 2008; Tawfik et al. 2010). Additional studies have proposed that HFS may protect the brain by regulating astrocytes (Fenoy et al. 2014). Recently, Jang and collaborators demonstrated that HFS induces the release of extracellular matrix proteins, such as insulin growth factor (IGF)-1 pathway, from human astrocytes in vitro (Jang et al. 2019), which protects neurons from excitotoxicity (Chen et al. 2019). However, the HFS/DBS effect on inflammatory astrocytes and its ability to affect the astrocytic secretory phenotype is completely unknown. Our in vivo data obtained from GP immunostained for GFAP demonstrates that STN-DBS partially reverses the effect of 6-OHDA on the hyperplasia phenomenon, which suggests an inhibition of astrocytic activation by DBS. It is important to note that astrocytic hyperplasia and increases in GFAP expression have also been described in conditions where astrocytes are believed to play an anti-inflammatory neuroprotective role (alternative A2 phenotype) (Barreto et al. 2011; Liddelow et al. 2017). Since DBS does not prevent 6-OHDA-induced astrocytic hyperplasia in the GP, future investigation should focus on whether DBS promotes astrocytic alternative anti-inflammatory (A2) activation.

Reactive astrogliosis is associated with increased release of pro-inflammatory cytokines such as TNF- $\alpha$ and IFN- $\gamma$, promoting inflammatory activation of microglial cells that further contributes to synaptic damage and neurodegeneration (McGeer and McGeer 2011). Several inflammatory cytokines including TNF- $\alpha$, IFN- $\gamma$, and MCP- 1 have been described in brain tissue, spinal fluid, and peripheral blood of PD patients (Gao and Hong 2008; Reale et al. 2009; Whitton 2009; Banks and Erickson 2010; Collins et al. 2012). We demonstrate that 6-OHDA not only induced an increase in the number of GFAP-positive cells in the GP 13 days after PD model induction, but also in IFN- $\gamma$ induction. In addition, 6-OHDA-induced IFN- $\gamma$ was completely attenuated by STN-DBS. IFN- $\gamma$ is a pro-inflammatory cytokine that acts as a potent glial activator (Schroder et al. 2004) and polarizes M0 subtype (resting state) macrophages/microglia to M1 subtype (pro-inflammatory state) (Chistiakov et al. 2018). In animal studies, increases in this cytokine are associated with the loss of dopaminergic neurons, nigrostriatal degeneration, and motor impairment (Mount et al. 2007; Barcia et al. 2011; Chakrabarty et al. 2011). In PD patients, high levels of IFN- $\gamma$ have been detected in the SN, striatum, cerebrospinal fluid, and plasma (Mogi et al. 1996; Hunot et al. 1999; Mount et al. 2007), which seems to contribute to the induction and maintenance of the neurodegenerative process (Gerhard et al. 2006; Brodacki et al. 2008). Our report is the first to show that the striatal 6-OHDA model produces pallidal IFN- $\gamma$ induction and that STN-DBS can reverse this phenomenon. Consistent with our findings, STN-DBS decreased IFN- $\gamma$ derived from T-helper-1 cells in PD, which seems to correlate with DBS efficacy (Soreq et al. 2013).

IL-10 is an anti-inflammatory cytokine released by glial cells in the central nervous system (CNS), and in response to 6-OHDA, it is also produced by T-helper-2 cells (Soreq et al. 2013). In the present study, we found an increase in pallidal IL-10 levels in response to 6-OHDA, which was completely abolished by DBS. Since IL-10 was shown to be a potent IFN- $\gamma$ inhibitor (Aharoni et al. 2000; Rengarajan et al. 2000), the increase in IL-10 levels following 6-OHDA may serve to inhibit or attenuate IFN- $\gamma$ production in an attempt to control the inflammatory response. Hence, the decreased levels of IL-10 after DBS may be a consequence of stimulation-induced decrease of IFN- $\gamma$.

Previous studies have shown that STN-DBS was able to decrease IL-6 expression in epileptic rats (Amorim et al. 2015; Chen et al. 2017). We found that IL-6 protein levels are significantly downregulated in the GP following 6-OHDA, when compared to saline-injected control rats. No detectable differences in pallidal IL-6 levels were found between 6-OHDA and 6-OHDA + DBS ON groups. Other studies showed no difference in IL-6 protein levels in both SN and striatum 12 days after 6-OHDA-induced PD in rats (Koprich et al. 2008).

Our data demonstrates that DBS significantly decreases 6-OHDA-induced astrocytic hyperplasia in the GP. Because of the importance of astrocytes in modulating the synaptic environment, these cells have been considered key mediators of DBS efficacy (Fenoy et al. 2014). In addition, astrocytes are an important source of pro-inflammatory cytokines and play a pivotal role in brain inflammation (Sofroniew 2014). We therefore used a model of mouse cultured astrocytes exposed to HFS and TNF- $\alpha$ to mimic in vivo DBS in PD and test whether HFS regulates 
Fig. 6 Representative DBS/HFS scheme suggested mechanism. Six-OHDA induces inflammation within the GP by activating A1, which attracts microglia cells and increases cytokines. STN-DBS/HFS while only slightly changing the number of astrocytes attenuates the classical inflammatory A1 astrocyte subtype by inhibiting NF- $\mathrm{KB}$ activation and cytokine release. The less activated astrocytes decrease microglia attraction reflecting in the inhibition of local cytokine release leading to improvement of inflammation within the GP

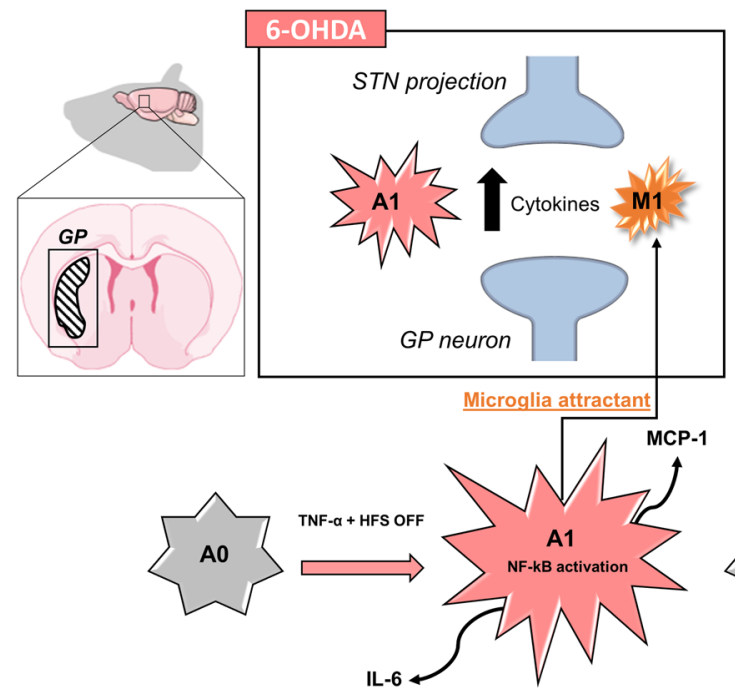

6-OHDA DBS ON

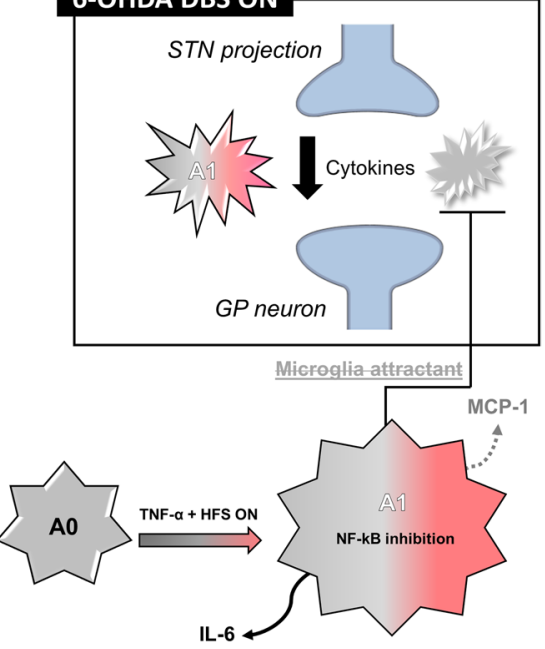

cytokine induction in astrocytes. While HFS does not seem to inhibit increased IL-6 mRNA levels, our data suggests that HFS significantly attenuates TNF- $\alpha$-stimulated MCP-1 induction at both the protein and mRNA levels. MCP-1 is a potent monocyte-attracting chemokine and has also been shown to attract M1 microglia to inflammation sites (Hinojosa et al. 2011), contributing to further enhance local brain neuroinflammation (Deshmane et al. 2009). The fact that HFS failed to prevent TNF- $\alpha$-induced IL-6 expression suggests that HFS specifically affects the secretion of determined cytokines and potentially specific transcription factors. While transcriptional regulation of IL-6 in astrocytes is mediated by both the pro-inflammatory transcription factor NF- $\mathrm{\kappa B}$ and the transcription factor activated by tyrosine kinases STAT3 (Hirano et al. 2000), MCP-1 expression is mainly regulated by NF- $\mathrm{KB}$ (Rovin et al. 1995; Schwamborn et al. 2003; Widera et al. 2004; Kigerl et al. 2009). NF-кB is a major CNS transcription factor and plays a pivotal role in glial cell function (O'Neill and Kaltschmidt 1997). Cytokines such as TNF- $\alpha$ activate the NF- $\mathrm{KB}$ signaling pathway by inducing the degradation of I $\kappa \mathrm{B}-\alpha$, an NF- $\kappa \mathrm{B}$ cytoplasmic inhibitor protein (Baeuerle and Baltimore 1988). Once IкB- $\alpha$ is degraded, the NF- $\mathrm{KB}$ p65 subunit translocates into the nuclei, activating the transcription of inflammatory cytokines (Baldwin 1996). In this study, we report that HFS not only regulates cytokine induction, but is also a novel regulator of NF- $\mathrm{KB}$ activation in astrocytes. Our results indicate that HFS prevents IкB- $\alpha$ degradation and inhibits TNF- $\alpha$-induced p65 nuclear translocation, supporting an uncovered antiinflammatory role for HFS in astrocytes. A limitation of our in vitro study is that experiments were performed in an astrocyte mouse cell line rather than a rat cell line. However, the concordance between in vitro and in vivo data makes this unlikely to be an issue.
We propose that one of the mechanisms by which DBS/ HFS inhibits neuroinflammation and improves motor impairment following PD is by decreasing astrocyte A1 subtype activation and microglia attractant, hence attenuating the overall inflammatory process (Fig. 6). Our findings demonstrate for the first time that DBS/HFS has a crucial role in inflammation inhibition, potentially regulating NF- $\kappa B$ activation. We suggest that DBS/HFS inhibits classical astrocytic activation, decreasing overall inflammation, while improving PD symptoms.

Author's Contributions ACPC, RLP, and MSH designed research. ACPC, AFNP, DSK, and MAK performed research. ACPC, RLP, and $\mathrm{MSH}$ analyzed data. ACPC, ETF, CH, RLP, and MSH wrote the paper. All authors read and approved the final manuscript.

Funding This work was supported by the São Paulo Research Foundation (FAPESP: A.C.P.C.-2016/07168-2 and 2017/14020-4), Hospital Sírio-Libanês (R.L.P), and American Heart Association (M.S.H.-17SDG33410777).

\section{Compliance with Ethical Standards}

Conflict of interest The authors declare that they have no competing interests.

Ethical Approval All animal-involved experiments were conducted in accordance with the laboratory animals care guidelines and approved by the Ethics Committee on the Use of Animals (CEUA) at Hospital Sírio-Libanês (SP, BRA), under protocol number CEUA 2016/04.

Open Access This article is licensed under a Creative Commons Attribution 4.0 International License, which permits use, sharing, adaptation, distribution and reproduction in any medium or format, as long as you give appropriate credit to the original author(s) and the source, provide a link to the Creative Commons licence, and indicate if changes were made. The images or other third party material in this article are included in the article's Creative Commons licence, unless indicated 
otherwise in a credit line to the material. If material is not included in the article's Creative Commons licence and your intended use is not permitted by statutory regulation or exceeds the permitted use, you will need to obtain permission directly from the copyright holder. To view a copy of this licence, visit http://creativecommons.org/licenses/by/4.0/.

\section{References}

Aharoni R, Teitelbaum D, Leitner O, Meshorer A, Sela M, Arnon $R$ (2000) Specific Th2 cells accumulate in the central nervous system of mice protected against experimental autoimmune encephalomyelitis by copolymer 1. Proc Natl Acad Sci USA 97:11472-11477. https://doi.org/10.1073/pnas.97.21.11472

Amorim BO, Covolan L, Ferreira E, Brito JG, Nunes DP, de Morais DG et al (2015) Deep brain stimulation induces antiapoptotic and anti-inflammatory effects in epileptic rats. J Neuroinflamm 12:162. https://doi.org/10.1186/s12974-015-0384-7

Amzica F, Neckelmann D (1999) Membrane capacitance of cortical neurons and glia during sleep oscillations and spike-wave seizures. J Neurophysiol 82:2731-2746. https://doi.org/10.1152/ jn.1999.82.5.2731

Amzica F, Massimini M, Manfridi A (2002) Spatial buffering during slow and paroxysmal sleep oscillations in cortical networks of glial cells in vivo. J Neurosci 22:1042-1053

Anglade P, Vyas S, Javoy-Agid F, Herrero MT, Michel PP, Marquez $\mathrm{J}$ et al (1997) Apoptosis and autophagy in nigral neurons of patients with Parkinson's disease. Histol Histopathol 12:25-31

Araque A, Parpura V, Sanzgiri RP, Haydon PG (1999) Tripartite synapses: glia, the unacknowledged partner. Trends Neurosci 22:208-215

Baeuerle P, Baltimore D (1988) I kappa B: a specific inhibitor of the NF-kappa B transcription factor. Science 242:540-546. https ://doi.org/10.1126/science. 3140380

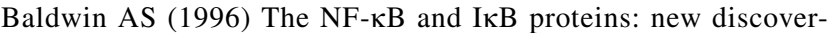
ies and insights. Annu Rev Immunol 14:649-681. https://doi. org/10.1146/annurev.immunol.14.1.649

Banks WA, Erickson MA (2010) The blood-brain barrier and immune function and dysfunction. Neurobiol Dis 37:26-32. https://doi.org/10.1016/j.nbd.2009.07.031

Barcia C, Ros CM, Annese V, Gómez A, Ros-Bernal F, AguadoLlera D et al (2011) IFN- $\gamma$ signaling, with the synergistic contribution of TNF- $\alpha$, mediates cell specific microglial and astroglial activation in experimental models of Parkinson's disease. Cell Death Dis 2:e142-e142. https://doi.org/10.1038/ cddis. 2011.17

Barreto G, White RE, Ouyang Y, Xu L, Giffard RG (2011) Astrocytes: targets for neuroprotection in stroke. Cent Nerv Syst Agents Med Chem 11:164-173

Bekar L, Libionka W, Tian G-F, Xu Q, Torres A, Wang X et al (2008) Adenosine is crucial for deep brain stimulation-mediated attenuation of tremor. Nat Med 14:75-80. https://doi. org/10.1038/nm1693

Benabid AL (2003) Deep brain stimulation for Parkinson's disease. Curr Opin Neurobiol 13:696-706

Benabid AL, Pollak P, Gross C, Hoffmann D, Benazzouz A, Gao DM et al (1994) Acute and long-term effects of subthalamic nucleus stimulation in Parkinson's disease. Stereotact Funct Neurosurg 62:76-84. https://doi.org/10.1159/000098600

Benabid AL, Chabardes S, Mitrofanis J, Pollak P (2009) Deep brain stimulation of the subthalamic nucleus for the treatment of Parkinson's disease. Lancet Neurol 8:67-81. https://doi. org/10.1016/S1474-4422(08)70291-6

Benazzouz A, Gross C, Féger J, Boraud T, Bioulac B (1993) Reversal of rigidity and improvement in motor performance by subthalamic high-frequency stimulation in MPTP-treated monkeys. Eur J Neurosci 5:382-389

Benazzouz A, Gao DM, Ni ZG, Piallat B, Bouali-Benazzouz R, Benabid AL (2000) Effect of high-frequency stimulation of the subthalamic nucleus on the neuronal activities of the substantia nigra pars reticulata and ventrolateral nucleus of the thalamus in the rat. Neuroscience 99:289-295

Beurrier C, Bioulac B, Audin J, Hammond C (2001) High-frequency stimulation produces a transient blockade of voltage-gated currents in subthalamic neurons. J Neurophysiol 85:1351-1356. https://doi.org/10.1152/jn.2001.85.4.1351

Boka G, Anglade P, Wallach D, Javoy-Agid F, Agid Y, Hirsch EC (1994) Immunocytochemical analysis of tumor necrosis factor and its receptors in Parkinson's disease. Neurosci Lett 172:151-154

Booth HDE, Hirst WD, Wade-Martins R (2017) The role of astrocyte dysfunction in Parkinson's disease pathogenesis. Trends Neurosci 40:358-370. https://doi.org/10.1016/j.tins.2017.04.001

Brodacki B, Staszewski J, Toczyłowska B, Kozłowska E, Drela N, Chalimoniuk $\mathrm{M}$ et al (2008) Serum interleukin (IL-2, IL-10, IL-6, IL-4), TNFalpha, and INFgamma concentrations are elevated in patients with atypical and idiopathic parkinsonism. Neurosci Lett 441:158-162. https://doi.org/10.1016/j.neule t.2008.06.040

Chakrabarty P, Ceballos-Diaz C, Lin W-L, Beccard A, Jansen-West $\mathrm{K}, \mathrm{McF}$ arland NR et al (2011) Interferon- $\gamma$ induces progressive nigrostriatal degeneration and basal ganglia calcification. Nat Neurosci 14:694-696. https://doi.org/10.1038/nn.2829

Charles PD, Dolhun RM, Gill CE, Davis TL, Bliton MJ, Tramontana MG et al (2012) Deep brain stimulation in early Parkinson's disease: enrollment experience from a pilot trial. Parkinsonism Relat Disord 18:268-273. https://doi.org/10.1016/j.parkreldis 2011.11.001

Chen Y-C, Zhu G-Y, Wang X, Shi L, Jiang Y, Zhang X et al (2017) Deep brain stimulation of the anterior nucleus of the thalamus reverses the gene expression of cytokines and their receptors as well as neuronal degeneration in epileptic rats. Brain Res 1657:304-311. https://doi.org/10.1016/j.brainres.2016.12.020

Chen W, He B, Tong W, Zeng J, Zheng P (2019) Astrocytic insulinlike growth factor- 1 protects neurons against excitotoxicity. Front Cell Neurosci 13:298. https://doi.org/10.3389/fncel.2019.00298.

Chiken S, Nambu A (2016) Mechanism of deep brain stimulation. Neuroscientist 22:313-322. https://doi.org/10.1177/1073858415 581986

Chistiakov DA, Myasoedova VA, Revin VV, Orekhov AN, Bobryshev YV (2018) The impact of interferon-regulatory factors to macrophage differentiation and polarization into M1 and M2. Immunobiology 223:101-111. https://doi.org/10.1016/j.imbio .2017.10.005

Chudler EH, Lu Y (2008) Nociceptive behavioral responses to chemical, thermal and mechanical stimulation after unilateral, intrastriatal administration of 6-hydroxydopamine. Brain Res 1213:4147. https://doi.org/10.1016/j.brainres.2008.03.053

Cicchetti F, Barker RA (2014) The glial response to intracerebrally delivered therapies for neurodegenerative disorders: is this a critical issue? Front Pharmacol 5:139. https://doi.org/10.3389/ fphar.2014.00139

Collins LM, Toulouse A, Connor TJ, Nolan YM (2012) Contributions of central and systemic inflammation to the pathophysiology of Parkinson's disease. Neuropharmacology 62:2154-2168. https ://doi.org/10.1016/j.neuropharm.2012.01.028

Cury RG, Galhardoni R, Teixeira MJ, dos Santos Ghilardi MG, Silva V, Myczkowski ML et al (2016) Subthalamic deep brain stimulation modulates conscious perception of sensory function in Parkinson's disease. Pain 157:2758-2765. https://doi. org/10.1097/j.pain.0000000000000697 
Dauer W, Przedborski S (2003) Parkinson's disease: mechanisms and models. Neuron 39:889-909

Deshmane SL, Kremlev S, Amini S, Sawaya BE (2009) Monocyte chemoattractant protein-1 (MCP-1): an overview. J Interf Cytokine Res 29:313-326. https://doi.org/10.1089/jir.2008.0027

Diamond A, Jankovic J (2005) The effect of deep brain stimulation on quality of life in movement disorders. J Neurol Neurosurg Psychiatry 76:1188-1193. https://doi.org/10.1136/jnnp.2005.065334

Domenici RA, Campos ACP, Maciel ST, Berzuino MB, Hernandes MS, Fonoff ET et al (2019) Parkinson's disease and pain: Modulation of nociceptive circuitry in a rat model of nigrostriatal lesion. Exp Neurol 315:72-81. https://doi.org/10.1016/j.expne urol.2019.02.007

dos-Santos-Pereira M, da-Silva CA, Guimarães FS, Del-Bel E, (2016) Co-administration of cannabidiol and capsazepine reduces L-DOPA-induced dyskinesia in mice: Possible mechanism of action. Neurobiol Dis 94:179-195. https://doi.org/10.1016/j. nbd.2016.06.013

Dostrovsky JO, Lozano AM (2002) Mechanisms of deep brain stimulation. Mov Disord 17(Suppl 3):S63-68

Duh EJ, Maury WJ, Folks TM, Fauci AS, Rabson AB (1989) Tumor necrosis factor alpha activates human immunodeficiency virus type 1 through induction of nuclear factor binding to the NFkappa B sites in the long terminal repeat. Proc Natl Acad Sci 86:5974-5978. https://doi.org/10.1073/pnas.86.15.5974

Fenoy AJ, Goetz L, Chabardès S, Xia Y (2014) Deep brain stimulation: are astrocytes a key driver behind the scene? CNS Neurosci Ther 20:191-201. https://doi.org/10.1111/cns.12223

Florence G, Sameshima K, Fonoff ET, Hamani C (2016) Deep brain stimulation: more complex than the inhibition of cells and excitation of fibers. Neuroscientist 22:332-345. https://doi. org/10.1177/1073858415591964

Gao H-M, Hong J-S (2008) Why neurodegenerative diseases are progressive: uncontrolled inflammation drives disease progression. Trends Immunol 29:357-365. https://doi.org/10.1016/j. it.2008.05.002

Gerhard A, Pavese N, Hotton G, Turkheimer F, Es M, Hammers A et al (2006) In vivo imaging of microglial activation with [11C](R)PK11195 PET in idiopathic Parkinson's disease. Neurobiol Dis 21:404-412. https://doi.org/10.1016/j.nbd.2005.08.002

Goodman RR, Kim B, McClelland S, Senatus PB, Winfield LM, Pullman SL et al (2006) Operative techniques and morbidity with subthalamic nucleus deep brain stimulation in 100 consecutive patients with advanced Parkinson's disease. J Neurol Neurosurg Psychiatry 77:12-17. https://doi.org/10.1136/jnnp.2005.069161

Gupta SC, Sundaram C, Reuter S, Aggarwal BB (2010) Inhibiting $\mathrm{NF}-\kappa \mathrm{B}$ activation by small molecules as a therapeutic strategy. Biochim Biophys Acta - Gene Regul Mech 1799:775-787. https ://doi.org/10.1016/j.bbagrm.2010.05.004

Haberler C, Alesch F, Mazal PR, Pilz P, Jellinger K, Pinter MM et al (2000) No tissue damage by chronic deep brain stimulation in Parkinson's disease. Ann Neurol 48:372-376

Hacker ML, Tonascia J, Turchan M, Currie A, Heusinkveld L, Konrad PE et al (2015) Deep brain stimulation may reduce the relative risk of clinically important worsening in early stage Parkinson's disease. Parkinsonism Relat Disord 21:1177-1183. https://doi. org/10.1016/j.parkreldis.2015.08.008

Hacker ML, Currie AD, Molinari AL, Turchan M, Millan SM, Heusinkveld LE et al (2016) Subthalamic nucleus deep brain stimulation may reduce medication costs in early stage Parkinson's disease. J Parkinsons Dis 6:125-131. https://doi.org/10.3233/ JPD-150712

Hamani C, Saint-Cyr JA, Fraser J, Kaplitt M, Lozano AM (2004) The subthalamic nucleus in the context of movement disorders. Brain 127:4-20. https://doi.org/10.1093/brain/awh029
Hamani C, Moro E, Lozano AM (2011) The pedunculopontine nucleus as a target for deep brain stimulation. J Neural Transm 118:14611468. https://doi.org/10.1007/s00702-010-0547-8

Hamani C, Florence G, Heinsen H, Plantinga BR, Temel Y, Uludag K, et al (2017) Subthalamic nucleus deep brain stimulation: basic concepts and novel perspectives. eNeuro 4:17. https://doi. org/10.1523/ENEURO.0140-17.2017

Harnack D, Kupsch A (2010) The impact of subthalamic deep brain stimulation on nigral neuroprotection-myth or reality? Neuromodulation Technol Neural Interface 13:160-167. https://doi. org/10.1111/j.1525-1403.2010.00282.x

Hashimoto Y, Ota T, Mukaino M, Ushiba J (2013) Treatment effectiveness of brain-computer interface training for patients with focal hand dystonia: a double-case study. Conf Proc Annu Int Conf IEEE Eng Med Biol Soc IEEE Eng Med Biol Soc Annu Conf 2013:273-276. https://doi.org/10.1109/ EMBC.2013.6609490

Hinojosa AE, Garcia-Bueno B, Leza JC, Madrigal JLM (2011) CCL2/ MCP-1 modulation of microglial activation and proliferation. J Neuroinflamm 8:77. https://doi.org/10.1186/1742-2094-8-77

Hirano T, Ishihara K, Hibi M (2000) Roles of STAT3 in mediating the cell growth, differentiation and survival signals relayed through the IL-6 family of cytokine receptors. Oncogene 19:2548-2556. https://doi.org/10.1038/sj.onc.1203551

Hunot S, Dugas N, Faucheux B, Hartmann A, Tardieu M, Debré P et al (1999) FcepsilonRII/CD23 is expressed in Parkinson's disease and induces, in vitro, production of nitric oxide and tumor necrosis factor-alpha in glial cells. J Neurosci 19:3440-3447

Jang E, Kim J-H, Lee S, Kim J-H, Seo J-W, Jin M et al (2013) Phenotypic polarization of activated astrocytes: the critical role of lipocalin-2 in the classical inflammatory activation of astrocytes. J Immunol 191:5204-5219. https://doi.org/10.4049/jimmu nol.1301637

Jang JS, Choi CI, Yi J, Butters K, Kim I, Bhagwate A, et al (2019) High frequency electrical stimulation promotes expression of extracellular matrix proteins from human astrocytes. Mol Biol Rep 46:4369-4375. https://doi.org/10.1007/s11033-019-04890-9.

Jha MK, Lee S, Park DH, Kook H, Park K-G, Lee I-K et al (2015) Diverse functional roles of lipocalin-2 in the central nervous system. Neurosci Biobehav Rev 49:135-156. https://doi. org/10.1016/j.neubiorev.2014.12.006

Joers V, Tansey MG, Mulas G, Carta AR (2017) Microglial phenotypes in Parkinson's disease and animal models of the disease. Prog Neurobiol 155:57-75. https://doi.org/10.1016/j.pneur obio.2016.04.006

Kigerl KA, Gensel JC, Ankeny DP, Alexander JK, Donnelly DJ, Popovich PG (2009) Identification of two distinct macrophage subsets with divergent effects causing either neurotoxicity or regeneration in the injured mouse spinal cord. J Neurosci 29:1343513444. https://doi.org/10.1523/JNEUROSCI.3257-09.2009

Kleiner-Fisman G, Herzog J, Fisman DN, Tamma F, Lyons KE, Pahwa $R$ et al (2006) Subthalamic nucleus deep brain stimulation: summary and meta-analysis of outcomes. Mov Disord 21:S290 S304. https://doi.org/10.1002/mds.20962

Koprich JB, Reske-Nielsen C, Mithal P, Isacson O (2008) Neuroinflammation mediated by IL-1beta increases susceptibility of dopamine neurons to degeneration in an animal model of Parkinson's disease. J Neuroinflamm 5:8. https://doi. org/10.1186/1742-2094-5-8

Korn T, Magnus T, Jung S (2005) Autoantigen specific T cells inhibit glutamate uptake in astrocytes by decreasing expression of astrocytic glutamate transporter GLAST: a mechanism mediated by tumor necrosis factor- $\alpha$. FASEB J 19:1878-1880

Krack P, Limousin P, Benabid AL, Pollak P (1997) Chronic stimulation of subthalamic nucleus improves levodopa-induced dyskinesias 
in Parkinson's disease. Lancet (London, England) 350:1676. https://doi.org/10.1016/s0140-6736(05)64273-0

Kumar R, Lozano AM, Kim YJ, Hutchison WD, Sime E, Halket E et al (1998) Double-blind evaluation of subthalamic nucleus deep brain stimulation in advanced Parkinson's disease. Neurology 51:850-855. https://doi.org/10.1212/wnl.51.3.850

Lagrange E, Krack P, Moro E, Ardouin C, Van Blercom N, Chabardes $\mathrm{S}$ et al (2002) Bilateral subthalamic nucleus stimulation improves health-related quality of life in PD. Neurology 59:1976-1978. https://doi.org/10.1212/01.wnl.0000037486 $.82390 .1 \mathrm{c}$

Lang AE, Lozano AM (1998) Parkinson's disease. N Engl J Med 339:1044-1053. https://doi.org/10.1056/NEJM19981008339 1506

Liddelow SA, Guttenplan KA, Clarke LE, Bennett FC, Bohlen CJ, Schirmer L et al (2017) Neurotoxic reactive astrocytes are induced by activated microglia. Nature 541:481-487. https:// doi.org/10.1038/nature21029

Maesawa S, Kaneoke Y, Kajita Y, Usui N, Misawa N, Nakayama A et al (2004) Long-term stimulation of the subthalamic nucleus in hemiparkinsonian rats: neuroprotection of dopaminergic neurons. J Neurosurg 100:679-687. https://doi.org/10.3171/ jns.2004.100.4.0679

Marsden CD (1990) Parkinson's disease. Lancet (London, England) 335:948-952. https://doi.org/10.1016/0140-6736(90)91006-v

McGeer PL, McGeer EG (2008) Glial reactions in Parkinson's disease. Mov Disord 23:474-483. https://doi.org/10.1002/ mds. 21751

McGeer PL, McGeer EG (2011) History of innate immunity in neurodegenerative disorders. Front Pharmacol 2:77. https://doi. org/10.3389/fphar.2011.00077

Mishima T, Sakatani S, Hirase H (2007) Intracellular labeling of single cortical astrocytes in vivo. J Neurosci Methods 166:32-40. https ://doi.org/10.1016/j.jneumeth.2007.06.021

Mogi M, Harada M, Kondo T, Riederer P, Nagatsu T (1996) Interleukin-2 but not basic fibroblast growth factor is elevated in parkinsonian brain. J Neural Transm 103:1077-1081. https://doi. org/10.1007/BF01291792

Mogi M, Togari A, Tanaka K, Ogawa N, Ichinose H, Nagatsu T (2000) Increase in level of tumor necrosis factor-alpha in 6-hydroxydopamine-lesioned striatum in rats is suppressed by immunosuppressant FK506. Neurosci Lett 289:165-168

Mount MP, Lira A, Grimes D, Smith PD, Faucher S, Slack R et al (2007) Involvement of interferon-gamma in microglial-mediated loss of dopaminergic neurons. J Neurosci 27:3328-3337. https:// doi.org/10.1523/JNEUROSCI.5321-06.2007

Nagatsu T, Sawada M (2005) Inflammatory process in Parkinson's disease: role for cytokines. Curr Pharm Des 11:999-1016

O'Neill LA, Kaltschmidt C (1997) NF-kappa B: a crucial transcription factor for glial and neuronal cell function. Trends Neurosci 20:252-258

Obeso JA, Rodriguez-Oroz MC, Lanciego JL, Diaz MR (2004) How does Parkinson's disease begin? The role of compensatory mechanisms. Trends Neurosci 27:125-127. https://doi.org/10.1016/j. tins.2003.12.006

Paxinos G, Watson C (2005) The rat brain in stereotaxic coordinates. Academic Press, New York

Perea G, Navarrete M, Araque A (2009) Tripartite synapses: astrocytes process and control synaptic information. Trends Neurosci 32:421-431. https://doi.org/10.1016/j.tins.2009.05.001

Piboolnurak P, Lang AE, Lozano AM, Miyasaki JM, Saint-Cyr JA, Poon Y-YW et al (2007) Levodopa response in long-term bilateral subthalamic stimulation for Parkinson's disease. Mov Disord 22:990-997. https://doi.org/10.1002/mds.21482

Reale M, Iarlori C, Thomas A, Gambi D, Perfetti B, Di Nicola M et al (2009) Peripheral cytokines profile in Parkinson's disease. Brain Behav Immun 23:55-63. https://doi.org/10.1016/j. bbi.2008.07.003

Rengarajan J, Szabo SJ, Glimcher LH (2000) Transcriptional regulation of Th1/Th2 polarization. Immunol Today 21:479-483

Ross GW, Petrovitch H, Abbott RD, Nelson J, Markesbery W, Davis D et al (2004) Parkinsonian signs and substantia nigra neuron density in decendents elders without PD. Ann Neurol 56:532-539. https://doi.org/10.1002/ana.20226

Rovin BH, Dickerson JA, Tan LC, Hebert CA (1995) Activation of nuclear factor-kappa B correlates with MCP-1 expression by human mesangial cells. Kidney Int 48:1263-1271

Sanberg PR (1980) Haloperidol-induced catalepsy is mediated by postsynaptic dopamine receptors. Nature 284:472-473

Sanchez-Guajardo V, Tentillier N, Romero-Ramos M (2015) The relation between $\alpha$-synuclein and microglia in Parkinson's disease: Recent developments. Neuroscience 302:47-58. https:// doi.org/10.1016/j.neuroscience.2015.02.008

Sawada M, Imamura K, Nagatsu T (2006) Role of cytokines in inflammatory process in Parkinson's disease. J Neural Transm Suppl 70:373-381

Schroder K, Hertzog PJ, Ravasi T, Hume DA (2004) Interferon- $\gamma$ : an overview of signals, mechanisms and functions. J Leukoc Biol 75:163-189. https://doi.org/10.1189/jlb.0603252

Schwamborn J, Lindecke A, Elvers M, Horejschi V, Kerick M, Rafigh M et al (2003) Microarray analysis of tumor necrosis factor alpha induced gene expression in U373 human glioblastoma cells. BMC Genomics 4:46. https://doi. org/10.1186/1471-2164-4-46

Sofroniew MV (2014) Multiple roles for astrocytes as effectors of cytokines and inflammatory mediators. Neuroscientist 20:160 172. https://doi.org/10.1177/1073858413504466

Sofroniew MV, Vinters HV (2010) Astrocytes: biology and pathology. Acta Neuropathol 119:7-35. https://doi.org/10.1007/s0040 1-009-0619-8

Soreq L, Bergman H, Israel Z, Soreq H (2013) Deep brain stimulation modulates nonsense-mediated RNA decay in Parkinson's patients leukocytes. BMC Genomics 14:478. https://doi. org/10.1186/1471-2164-14-478

Spieles-Engemann AL, Behbehani MM, Collier TJ, Wohlgenant SL, Steece-Collier K, Paumier K et al (2010) Stimulation of the rat subthalamic nucleus is neuroprotective following significant nigral dopamine neuron loss. Neurobiol Dis 39:105-115. https ://doi.org/10.1016/j.nbd.2010.03.009

Stock G, Sturm V, Schmitt HP, Schlör KH (1979) The influence of chronic deep brain stimulation on excitability and morphology of the stimulated tissue. Acta Neurochir (Wien) 47:123-129

Stott SRW, Barker RA (2014) Time course of dopamine neuron loss and glial response in the 6-OHDA striatal mouse model of Parkinson's disease. Eur J Neurosci 39:1042-1056. https://doi. org/10.1111/ejn.12459

Sun DA, Yu H, Spooner J, Tatsas AD, Davis T, Abel TW et al (2008) Postmortem analysis following 71 months of deep brain stimulation of the subthalamic nucleus for Parkinson disease. J Neurosurg 109:325-329. https://doi.org/10.3171/JNS/2008/109/8/0325

Tawfik VL, Chang S-Y, Hitti FL, Roberts DW, Leiter JC, Jovanovic S et al (2010) Deep brain stimulation results in local glutamate and adenosine release: investigation Into the role of astrocytes. Neurosurgery 67:367-375. https://doi.org/10.1227/01.NEU.00003 $71988.73620 .4 \mathrm{C}$

Verma IM, Stevenson JK, Schwarz EM, Van Antwerp D, Miyamoto S (1995) Rel/NF-kappa B/I kappa B family: intimate tales of association and dissociation. Genes Dev 9:2723-2735. https:// doi.org/10.1101/gad.9.22.2723

Whitton PS (2009) Inflammation as a causative factor in the aetiology of Parkinson's disease. Br J Pharmacol 150:963-976. https://doi. org/10.1038/sj.bjp.0707167 
Widera D, Holtkamp W, Entschladen F, Niggemann B, Zänker K, Kaltschmidt B et al (2004) MCP-1 induces migration of adult neural stem cells. Eur J Cell Biol 83:381-387. https://doi. org/10.1078/0171-9335-00403

Zhang X, Andren PE, Greengard P, Svenningsson P (2008) Evidence for a role of the 5-HT1B receptor and its adaptor protein, p11, in L-DOPA treatment of an animal model of Parkinsonism. Proc Natl Acad Sci U S A 105:2163-2168. https://doi.org/10.1073/ pnas.0711839105
Publisher's Note Springer Nature remains neutral with regard to jurisdictional claims in published maps and institutional affiliations. 